\title{
FAKTOR-FAKTOR YANG BERHUBUNGAN DENGAN PERILAKU KONSUMSI MAKANAN CEPAT SAJI (FAST FOOD) PADA MAHASISWA
}

\author{
Factors that are Related to Behavior of Fast Food Food Consumption in Students \\ Dede Munasiroh, Diana Oktavia Nurawali, Dina Aulia Rahmah, Fina Suhailah, \\ Iwan Ridwan Yusup \\ Universitas Islam Negeri Bandung \\ Email : dede.afnan20@gmail.com
}

\begin{abstract}
The fast-paced mindset of people causes people to want everything to be instant, so that the habit of consuming fast food is now a phenomenon. The purpose of this study was to determine the relationship between independent and dependent variables (age, gender, nutritional status, knowledge, population movements, pocket money, social support, information sources and access to facilities) to students. This type of research uses a cross sectional design, where data collection was conducted in November 2018. The population in this study were students majoring in biology education with a total of 481 students. The sample in this study were 61 students. The technique in taking research data was obtained through a questionnaire. Data from this study were processed using the chi square test univariate dan bivariate. Factors that influence the behavior of fast food consumption are nutritional status and social support. While unrelated factors are age, gender, knowledge, population movement, pocket money, sources of information, and access to facilities. This research recommends to maintain eating behavior to avoid obesity, prevent disease and malnutrition.
\end{abstract}

Keywords: Fast food, consumption behavior, students

\begin{abstract}
Abstrak
Pola pemikiran masyarakat yang serba cepat menyebabkan manusia menginginkan segala sesuatunya menjadi serba instant, sehingga kebiasaan mengkonsumsi makanan cepat saji saat ini. Tujuan penelitian ini adalah untuk mengetahui hubungan variabel bebas dan terikat (umur, jenis kelamin, status gizi, pengetahuan, perpindahan penduduk, uang saku, dukungan sosial, sumber informasi dan akses sarana) pada mahasiswa. Jenis Penelitian ini menggunakan desain cross sectional, dimana pengumpulan data dilakukan pada bulan November 2018. Populasi dalam penelitian ini adalah mahasiswa jurusan pendidikan biologi dengan jumlah 481 mahasiswa. Sampel dalam penelitian ini sebanyak 61 mahasiswa. Teknik dalam pengambilan data penelitian diperoleh melalui kuesioner. Data hasil penelitian ini diolah dengan menggunakan uji chi square univariat dan bivariat. Faktor-faktor yang mempengaruhi perilaku konsumsi makanan cepat saji yaitu status gizi dan dukungan sosial. Sedangkan faktor yang tidak berhubungan yaitu umur, jenis kelamin, pengetahuan, perpindahan penduduk, uang saku, sumber informasi, dan akses sarana. Penelitian ini merekomendasikan untuk mempertahankan perilaku makan agar terhindar dari obesitas, mencegah penyakit dan gizi buruk.
\end{abstract}

Kata Kunci : Makanan cepat saji, perilaku konsumsi, mahasiswa 


\section{PENDAHULUAN}

Kegiatan mengonsumsi makanan adalah kebutuhan sehari-hari yang diperlukan untuk memenuhi gizi yang nantinya akan berguna di dalam tubuh sebagai pemenuhan dasar manusia yang paling utama. Terbentuknya kebiasaan konsumsi yang mana akan membentuk perilaku konsumsi secara berulang-ulang. Pola pemikiran masyarakat yang serba cepat menyebabkan manusia menginginkan segala sesuatunya menjadi serba instant. Menurut Kementrian Kesehatan mayoritas anak pada tahun 2011 memiliki perilaku makan yang buruk seperti mengonsumsi makanan asin sebanyak $24,5 \%$, mengonsumsi makanan dan minuman manis sebanyak 65,2\%, kurangnya mengonsumsi sayur sebanyak 93,6\% dan buah-buahan 62,1\% serta melewatkan sarapan 60\% (Kemenkes RI, 2011).

Pada masa remaja pemilihan makanan juga tidak lagi didasarkan pada kandungan gizi tetapi juga untuk bersosialisasi, untuk kesenangan, dan supaya tidak kehilangan stasus. Berdasarkan hasil penelitian (Lutfi, 2011) mahasiswa memilih fast food karena penyajian cepat sehingga hemat waktu dan dapat dihidangkan kapan dan dimana saja, tempat saji dan penyajian yang higienis, harga yang terjangkau, jenis makanannya memenuhi selera, dianggap makanan bergengsi, makanan modern, juga makanan gaul bagi anak muda.

Menurut hasil penelitian yang dilakukan oleh Health Education Authority, usia 15-34 tahun adalah konsumen terbanyak yang memilih menu fast food. Hasil penelitian sebelumnya memang menemukan adanya kaitan antara riwayat kebiasaan mengkonsumsi makanan tinggi kalori dan lemak seperti fast food dengan obesitas (Wulandari, 2006). Tujuan penelitian ini adalah untuk mengetahui faktor-faktor yang berhubungan dengan pemilihan makanan siap saji (fast food) mahasiswa jurusan pendidikan biologi UIN Sunan Gunung Djati Bandung.

\section{BAHAN DAN METODE}

Jenis penelitian ini menggunakan desain "cross sectional" untuk melihat faktor-faktor yang berhubungan dengan perilaku konsumsi makanan cepat saji (fast food). Populasi penelitian ini adalah mahasiswa semester 1, 3, 5, dan 7 jurusan pendidikan biologi UIN Sunan Gunung Djati Bandung yang berjumlah 481 mahasiswa, sedangkan jumlah sampel 61 mahasiswa. Pengumpulan data dilakukan dengan menggunakan kuesioner untuk mendapatkan data sikap, pengetahuan gizi, penggunaan media, dukungan sosial, akses sarana dan pendapatan uang saku mahasiswa. Data yang telah terkumpul kemudian dianalisis menggunakan uji Chi-Square univariat dan bivariate dan diproses dengan program SPSS.

\section{HASIL DAN PEMBAHASAN}

\section{Analisis Univariat}

Tabel 1 menunjukkan bahwa dari 61 mahasiswa yang menjadi responden didapatkan mahasiswa berjenis kelamin perempuan sebanyak 55 responden (90, $2 \%$ ) sedangkan 6 responden mahasiswa berjenis kelamin laki-laki (9,8\%). Untuk responden yang berumur 19-20 tahun jumlahnya 26 $(42,6 \%)$ lebih sedikit dibandingkan dengan responden dengan umur 21-22 tahun yaitu sebanyak $35(57,4 \%)$. Sedangkan untuk responden dengan status gizi normal menunjukkan jumlah paling tinggi yaitu 48 responden $(78,6 \%)$.

Tabel 1. Distribusi Karakteristik berdasarkan Umur, Jenis Kelamin, Status Gizi

\begin{tabular}{lcc}
\hline Vaiabel & $\mathbf{n}$ & $\mathbf{0}$ \\
\hline Umur & & \\
18-20 tahun & 26 & 42,6 \\
21-22 tahun & 35 & 57,4 \\
Jenis Kelamin & & \\
Laki-laki & 6 & 9,8 \\
Perempuan & 55 & 90,2 \\
Status Gizi & & \\
Kurus & 8 & 13,1 \\
Normal & 48 & 78,6 \\
Gemuk & 5 & 8,1 \\
\hline Jumlah & 93 & 100 \\
\hline
\end{tabular}

\section{Analisis Bivariat}

Analisa bivariat dilakukan untuk melihat adanya hubungan antara faktor-faktor yang diduga berhubungan seperti (umur, jenis kelamin, pendapatan uang saku, pengetahuan, status gizi, perpindahan penduduk, sumber informasi dan akses sarana) dengan perilaku konsumsi makanan cepat saji mahasiswa pendidikan biologi UIN Sunan Gunung Djati Bandung. Hasil analisis bivariate dapat dilihat pada tabel 2 . 
Tabel 2. Faktor-Faktor yang Berhubungan dengan Perilaku Konsumsi Makanan Cepat Saji Mahasiswa Pendidikan Biologi UIN Sunan Gunung Djati Bandung

\begin{tabular}{|c|c|c|c|c|c|c|c|}
\hline \multirow{3}{*}{ Variabel } & \multirow{3}{*}{ Frekuensi } & \multirow{3}{*}{ Presentase } & \multicolumn{4}{|c|}{ Perilaku Konsumsi Makanan } & \multirow{3}{*}{ Nilai $\mathbf{P}$} \\
\hline & & & \multicolumn{2}{|c|}{ Kurang baik } & \multicolumn{2}{|c|}{ Baik } & \\
\hline & & & $\mathbf{N}$ & $\%$ & $\mathbf{N}$ & $\%$ & \\
\hline \multicolumn{8}{|l|}{ Umur } \\
\hline 18-20 tahun & 26 & 42,6 & 2 & 3,2 & 24 & 39,3 & 0,388 \\
\hline 21-22 tahun & 35 & 57,4 & 1 & 1,6 & 34 & 55,7 & \\
\hline \multicolumn{8}{|l|}{ Jenis Kelamin } \\
\hline Laki-Laki & 6 & 9,8 & 1 & 1,6 & 5 & 8,1 & 0,161 \\
\hline Perempuan & 55 & 90,2 & 2 & 3,2 & 53 & 86,8 & \\
\hline \multicolumn{8}{|l|}{ Status gizi } \\
\hline Kurus & 8 & 13,1 & 1 & 1,6 & 7 & 11,4 & 0,003 \\
\hline Normal & 48 & 78,6 & 2 & 3,2 & 46 & 75,4 & \\
\hline Gemuk & 5 & 8,1 & 0 & 0 & 5 & 8,1 & \\
\hline \multicolumn{8}{|l|}{ Pengetahuan } \\
\hline Kurang baik & 3 & 4,9 & 0 & 0 & 1 & 1,6 & 0,948 \\
\hline Baik & 58 & 95,1 & 3 & 4,9 & 57 & 93,4 & \\
\hline \multicolumn{8}{|c|}{ Perpindahan Penduduk } \\
\hline Tidak perpindah & 18 & 31,2 & 1 & 1,6 & 17 & 11,1 & 0,882 \\
\hline Berpindah & 42 & 68,8 & 2 & 3,2 & 41 & 67,2 & \\
\hline \multicolumn{8}{|l|}{ Uang saku } \\
\hline$>20.000$ & 29 & 47,5 & 1 & 1,6 & 28 & 45,9 & 0,613 \\
\hline$<20.000$ & 32 & 52,5 & 2 & 3,2 & 30 & 49,1 & \\
\hline \multicolumn{8}{|l|}{ Dukungan sosial } \\
\hline Kurang baik & 7 & 11,4 & 1 & 1,6 & 6 & 9,8 & 0,004 \\
\hline Baik & 54 & 88,5 & 2 & 67,5 & 13 & 21,3 & \\
\hline \multicolumn{8}{|l|}{ Sumber informasi } \\
\hline Kurang baik & 33 & 54,0 & 1 & 1,6 & 6 & 9,8 & 0,459 \\
\hline Baik & 28 & 45,9 & 1 & 1,6 & 52 & 42,6 & \\
\hline \multicolumn{8}{|l|}{ Akses sarana } \\
\hline Kurang baik & 6 & 9,8 & 1 & 1,6 & 5 & 8,1 & 0,161 \\
\hline Baik & 55 & 90,2 & 2 & 3,2 & 53 & 86,8 & \\
\hline
\end{tabular}

Responden dengan umur 21 sampai 22 tahun lebih cenderung untuk memiliki perilaku konsumsi yang baik yaitu sebesar $(55,7 \%)$ dibandingkan dengan responden dengan umur 18 sampai 20 tahun sebesar $39,3 \%$. Hasil analisis statistik menunjukkan tidak ada hubungan antara umur dengan perilaku konsumsi makanan cepat saji. ( $P$ value 0,388 ). Hasil penelitian menunjukkan bahwa proporsi perempuan yang ikut penelitian ini lebih tinggi dibandingkan laki-laki. Sementara bila dilihat dari perilaku konsumsi makanannya, perempuan lebih banyak memiliki perilaku konsumsi makanan kategori baik sebesar (86,8\%) dibandingkan dengan responden laki-laki $(8,1 \%)$. Hasil uji Chi Square menunjukkan tidak ada hubungan antara jenis kelamin dengan perilaku konsumsi makanan cepat saji $(P$ value $=$ $0,161)$.

Tidak adanya hubungan antara jenis kelamin dengan pemilihan makanan cepat saji tersebut dimungkinka karena proporsi perempuaan yang ikut dalam penelitian ini lebih banyak daripada pada laki-laki, hal ini disebabkan karena presentase perempuan pada mahasiwa jurusan pendidikan biologi UIN Bandung secara keseluruhan memang jauh lebih tinggi sehingga dalam pengambilan sampel, perempuan lebih memiliki banyak kesempatan untuk terpilih menjadi responden penelitian, akibatnya hubungan jenis kelamin terhadap pemilihan makanan cepat saji ini bersifat homogen karena menurut Gibney et, all (2009) perempuan lebih cenderung menunjukan perhatiannya terhadap pemilihan makanan dari pada laki-laki, karena perempuan lebih menunjukan perhatian yang lebih besar pada keamanan pangan, kesehatan dan penurunan berat badan.

Dari hasil penelitian diketahui bahwa presentase repsonden yang tergolong status gizi normal lebih tinggi yaitu sebesar $78,6 \%$ 
dibandingkan dengan responden yang tergolong status gizi kurus yang hanya 13,1\% dan gemuk 8,1\% responden. Hasil analisis statistik menunjukan bahwa responden yang memiliki status gizi normal cenderung untuk melakukan perilaku konsumsi makanan baik yaitu sebesar (75,4\%) dibandingkan dengan responden yang memiliki status gizi kurus dan gemuk. Bila dilihat hubungannya, terdapat hubungan yang signifikan antara status gizi dengan pemilihan makanan cepat saji ( $p$-value $=0,003$ ).

Hubungan ini kemungkinan disebabkan karena seseorang yang memiliki status gizi normal, ia terbiasa untuk memilih makanan yang baik sehingga mempengaruhi status gizi mereka. Hal ini dapat terlihat dari beberapa variabel yang dapat menggambarkan perilaku makanan seperti; "memperhatikan konsumsi rendah kalori dan rendah lemak", responden yang memiliki status gizi normal lebih banyak menyatakan "kadang-kadang" memperhatikan asupan rendah lemak dan rendah kalori. Jika dilihat perilaku konsumsi makanan cepat saji orang yang memiliki status gizi kurus justru seharusnya mengarahkan mereka kepada status gizi yang lebih seperti pendapat yang dikemukakan Arisman (2004) yang menyatakan bahwa makanan olahan mengandung tinggi kalori dan lemak sehingga menyebabkan gizi lebih dan bisa mengarah pada obesitas.

Menurut (Sediaoetama 1996 dalam Azrimaidaliza 2011) orang yang semakin baik pengetahuan gizinya akan lebih banyak mempergunakan pertimbangan rasional dan pengetahuannya dibandingkan panca inderanya sebelum mengonsumsi makanan. Hasil penelitian menunjukan bahwa presentase responden yang memiliki pengetahuan baik lebih tinggi yaitu sebesar 95,1\% dibandingkan dengan responden yang memiliki pengetahuan kurang baik yaitu sebesar $4,9 \%$. Sementara hasil analisis statistik menunjukan bahwa responden yang memiliki pengetahuan kurang baik lebih sedikit pada responden yang melakukan perilaku konsumsi kurang baik pula yaitu sebesar (1,6\%) dibandingkan responden yang memiliki pengetahuan baik $(4,9 \%)$. Bila dilihat hubungannya, tidak ada hubungan antara pengetahuan terhadap perilaku konsumsi makanan cepat saji $(p$-value $=0,948)$. Hal ini sejalan dengan penelitian Yudita, D (2014) bahwa tidak ada hubungan antara pengetahuan responden dengan perilaku makan mahasiswa.

Sedangkan menurut (Green, 2000) yang menyatakan bahwa responden dengan pengetahuan yang buruk dapat memiliki perilaku makan yang buruk dikarenakan tingkah laku manusia sematamata ditentukan oleh kemampuan berfikirnya, karena perilaku tanpa didasari pengetahuan yang baiktidak akan menimbulkan hasil yang baik.

Tidak adanya hubungan antara pengetahuan dengan perilaku konsumsi makanan cepat saji kemungkinan disebabkan karena faktor lain yang lebih besar dari pada pengaruh pengetahuan.

\section{Hubungan Perpindahan Penduduk dengan Perilaku Konsumsi Makanan Cepat Saji}

Perbedaan tempat tinggal juga mempengaruhi pilihan makanan. Hal ini berhubungan dengan lokasi geografis yang berkontribusi terhadap ketersediaan pangan dan biaya makanan (Dorothy, 2006). Hasil analisis statistik menunjukkan jumlah responden yang mengekos/perpindahan tempat tinggal lebih banyak yaitu sebesar $68,8 \%$ dibandingkan dengan responden yang tidak berpindah tempat tinggal yaitu sebesar 31,2\% responden. Sementara, bila dilihat kecenderungannya responden yang memiliki perilaku konsumsi makanan baik lebih banyak pada responden yang berpindah tempat tinggal/mengekos (67,2\%) dibandingkan dengan responden yang tidak berpindah tempat tinggal/mengekos (11,1\%).

Hal ini kemungkinan disebabkan responden yang berpindah tempat tinggal jumlahnya lebih banyak dibandingkan dengan responden yang tidak berpindah tempat tinggal. Sementara bila dilihat hubungannya, tidak ada hubungan antara perpindahan penduduk dengan pemilihan makanan cepat saji ( $p$-value $=0,882$ ).

Tidak adanya hubungan antara perpindahan penduduk dengan pemilihan makanan cepat saji kemungkinan disebabkan karena variasi makanan yang ditawarkan ditempat tinggal saat kuliah tidak berbeda jauh dengan variasi makanan di tempat tinggal aslinya. Sehingga dalam hal ini walaupun terdapat perbedaan geografis namun makanan yang tersedia sama dengan lingkungan sebelumnya, hal ini menyebakan pemilihan makanan responded tidak jauh berbeda dengan pemilihan makanan di tempat asalnya. Akibatnya dalam hal ini 
perpindahan penduduk tidak mempengaruhi perilaku makanan cepat saji.

\section{Hubungan Pendapatan Uang Saku dengan Perilaku Konsumsi Makanan Cepat Saji}

Berdasarkan hasil penelitian, mahasiswa yang mengeluarkan uang saku untuk pengeluaran makanan diatas rata-rata yaitu < Rp. 20000 lebih tinggi 32 (52,5\%) dibandingkan dengan pengeluaran yang dibawah rata-rata > Rp. 20000 sebesar 29 $(47,5 \%)$, sementara hasil analisis statistik menunjukkan bahwa responden yang memiliki uang saku dibawah rata-rata < Rp. 20000 lebih banyak memiliki pemilihan makanan baik yaitu sebesar $(49,1 \%)$ dibandingkan dengan responden yang memiliki uang saku diatas rata-rata >Rp.20000 $(45,9 \%)$. Bila dilihat hubungannya, tidak ada hubungan antara uang saku dengan pemilihan makanan cepat saji ( $p$-value $=0,613)$. Hal ini tidak sejalan dengan penelitian (Masthalina dkk, 2013) yang menyatakan bahwa ketersediaan uang saku yang diterima remaja akan mempengaruhi pola konsumsi makanan cepat saji. Semakin besar uang saku yang dimiliki remaja, maka semakin banyak dan semakin sering remaja mengonsumsi makanan cepat saji.

Tidak adanya hubungan disini kemungkinan disebabkan oleh faktor lain yaitu status kesehatan/status gizi lebih dominan pengaruhnya dalam pemilihan makanan daripada uang saku.

\section{Hubungan dukungan sosial dengan perilaku konsumsi makanan cepat saji}

Pada penelitian ini terdapat hubungan dukungan sosial dengan perilaku konsumsi karena nilai $(p$-value $=0,004)$. Hal ini sejalan dengan penelitian yang menyatakan dukungan sosial seperti teman sebaya juga menjadi penyebab tingginya konsumsi makanan cepat saji pada remaja. Padahal remaja tersebut sudah mengetahui bahaya makanan cepat saji bagi kesehatan. Selain itu, remaja lebih senang makan bersama teman-temannya daripada makan di rumah, sehingga dapat menyebabkan remaja memiliki kebiasaan makan yang buruk (Mustikaningsih dkk, 2015). Menurut Keller dalam (Rahman, 2016) kekuatan dari teman sepermainan sangat kuat pada masa anak-anak dan remaja karena kebanyakan waktunya dihabiskan di sekolah atau di tempat lain bersama dengan temannya, sehingga teman sepermainan dapat mengubah perilaku dan kebiasaan yang baik dan sehat berkaitan dengan perilaku makan. Pada penelitian FGD yang dilakukan, ajakan teman sebaya menjadi salah satu faktor yang mempengauhi remaja untuk memilih makanan cepat saji atau fast food dibandingkan dengan makanan lainnya (Nusa dkk, 2013).

Selain dukungan dari teman sebaya, faktor dukungan atau peran orang tua juga berhubungan dengan perilaku konsumsi makanan cepat saji. Hasil ini juga didukung dengan penelitian Cooke (2004) bahwa ada hubungan antara peran orang tua dengan perilaku makan anak gizi lebih, didukung oleh pendapat Cahyaningsih (2011) menyatakan bahwa walaupun kelompok teman sebaya berpengaruh dan penting untuk perkembangan anak secara normal, namun orang tua merupakan pengaruh utama dalam membentuk kepribadian anak dan membuat standar kebiasaan.

\section{Hubungan Sumber Informasi dengan Perilaku Konsumsi Makanan Cepat Saji}

Hasil penelitian menunjukan bahwa presentase responden yang memiliki sumber informasi kurang baik baik lebih tinggi yaitu sebesar $54 \%$ dibandingkan dengan responden yang memiliki sumber informasi baik yaitu sebesar $45,9 \%$. Sementara hasil analisis statistik menunjukan bahwa responden yang memiliki sumber informasi baik lebih banyak pada responden yang melakukan pemilihan makanan baik pula yaitu sebesar $(42,6 \%)$ dibandingkan responden yang memiliki sumber informasi kurang baik (9,8\%). Bila dilihat hubungannya, tidak ada hubungan antara sumber informasi terhadap perilaku konsumsi makanan cepat saji $(p$-value $=0,459)$. Karena biasanya semakin banyak informasi yang diperoleh, maka akan semakin tinggi pula pengetahuan yang didapat oleh seseorang tersebut sehingga akan memperhatikan perilaku konsumsi makanan cepat saji.

\section{Hubungan akses sarana dengan perilaku konsumsi makanan cepat saji}

Didapatkan dari penelitian ini bahwa ketersediaan akses sarana terhadap perilaku konsumsi makanan cepat saji responden sudah baik (90,2\%). Hasil penelitian menunjukan bahwa presentase responden yang memiliki akses sarana baik lebih tinggi yaitu sebesar 90,2\% dibandingkan 
dengan responden yang memiliki akses sarana kurang baik yaitu sebesar 9,8\%. Sementara hasil analisis statistik menunjukan bahwa responden yang memiliki akses sarana baik lebih banyak pada responden yang melakukan pemilihan makanan baik pula yaitu sebesar $(86,8 \%)$ dibandingkan responden yang memiliki pengetahuan kurang baik $(8,1 \%)$. Bila dilihat hubungannya, tidak ada hubungan antara pengetahuan terhadap perilaku konsumsi makanan cepat saji $(p$-value $=0,161)$. Hasil penelitian ini sejalan dengan penelitian Nova, A (2011) bahwa tidak ada hubungan antara ketersediaan sarana prasarana dengan perilaku makan anak gizi lebih.

\section{KESIMPULAN DAN SARAN}

Berdasarkan hasil penelitian didapatkan bahwa tidak ada hubungan antara umur, jenis kelamin, pendapatan uang saku, sumber informasi, pengetahuan, perpindahan penduduk, dan akses sarana terhadap perilaku konsumsi makanan cepat saji mahasiswa pendidikan biologi UIN Bandung Tahun 2019 namun terdapat hubungan yang signifikan pada variabel status gizi dan dukungan sosial seperti peran teman dan keluarga.

Pemilihan makanan pada mahasiswa pendidikan biologi lebih mengarah pada kesadaran akan keamanan pangan, namun rendah perhatiannya dalam hal kandungan gizi dari makanan cepat saji tersebut. Oleh karena itu, akan lebih baik jika keduanya mendapat perhatian yang sama. Perhatian akan kandungan gizi bisa mengurangi resiko terjadinya penyakit degeneratif di kemudian hari. Diharapkan untuk mahasiswa lebih memperhatikan pemilihan makanannya, terutama yang berpengaruh terhadap status gizi. Penelitian selanjutnya disarankan agar menggunakan metode lain dalam meneliti perilaku konsumsi makanan cepat saji, misalnya melalui wawancara mendalam terhadap mahasiswa, sehingga informasi yang diperoleh dapat lebih bervariasi dan akurat dari pada angket yang jawabannya telah tersedia.

\section{DAFTAR PUSTAKA}

Arisman. 2004. Gizi Dalam Daur Kehidupan. EGC Kedokteran: Jakarta

Azrimaidaliza, Idral Punakarya. 2011. Faktor-faktor yang mempengaruhi pemilihan makanan pada remaja di kota padang sumatera barat tahun
2008. Jurnal kesehatan masyarakat.volume, 6 nomor 1 .

Cahyaningsih, D., S. 2011. Pertumbuhan Perkembangan Anak dan Remaja. Jakarta: Rineka Cipta.

Gibney, Michael J, et al. 2009. Gizi Kesehatan Masyarakat. EGC Kedokteran : Jakarta.

Green L, Marshall K. 2000. Health Promotion Planning An Educational and Environmental Approach. Montain View, Toronto Londong: Mayfield Publishing Company.

Kementrian Kesehatan RI. 2011. Strategi Nasional Penerapan Pola Konsumsi Makanan Dan Aktivitas Fisik Untuk Mencegah Penyakit. Direktorat Jenderal Bina Gizi dan Kesehatan Ibu dan Anak. Jakarta.

Lutfi, S. 2011. Makan Teratur Mahasiswa Tingkat Akhir. Dikutipdarihttp://lutiblurry.com (diakses 10 November 2016).

Masthalina, H., Suhaema, Mizwar, M. 2013 Ketersediaan Uang Saku, Aktivitas dan Pengetahuan Remaja Berhubungan dengan Pola Konsumsi Fast Food di SMAN 1 Mataram. Jurnal Media Gizi Pangan.

Mustikaningsih, D., Hartini, T.N.S. \& Syamsiatun, N.H. 2015. Persepsi tentang Fast Food dan Frekuensi Konsumsi Fast Food sebagai Faktor Risiko Terjadinya Obesitas pada Remaja di Yogyakarta. Jurnal Nutrisia. Vol. 17 No. 2.

Nova Yorika, A. 2011. Hubungan Faktor-Faktor yang Mempengaruhi Jajan pada Anak SD Kelas I dan II dengan Perilaku Jajan Sembarangan di SD Negeri Cokrokusuman Kecamatan Jetis Yogyakarta. Skripsi. Program Studi Ilmu Keperawatan. Sekolah Tinggi Ilmu Kesehatan 'Aisyiyah.

Nusa, A.F.A. \& Adi, A.C. 2013. Hubungan Faktor Perilaku, Frekuensi Konsumsi Fast Food, Diet dan Genetik dengan Tingkat Kelebihan Berat Badan. Media Gizi Indonesia. Vol. 9 No. 1.

Rahman, N. 2016. Faktor-Faktor yang Berhubungan dengan Perilaku Makan pada Remaja SMA Negeri 1 Palu. Jurnal Program Studi Kesehatan Masyarakat. Fakultas Kedokteran dan Ilmu Kesehatan. Universitas Tadulako.

West, Dorothy. 2006. Influence on Nutritional Practices and Wellness Across the Lifespan. 